\title{
Ureteroscopy Outcomes, Complications and Management of Perforations in Impacted Ureter Stones
}

\section{Impakte Üreter Taşlarında Üreteroskopinin Sonuçları, Komplikasyonları ve Gelişen Perforasyonlara Yaklaşım}

\author{
Göksel Bayar¹, Orhan Tanrıverdi2, Kaya Horasanlı³, Ayhan Dalkılıç3 \\ 1/dil State Hospital, Clinic of Urology, Şırnak, Turkey \\ 2Bahçeşehir University Faculty of Medicine, Liv Hospital, Clinic of Urology, İstanbul, Turkey \\ 3Şişli Hamidiye Etfal Training and Research Hospital, Clinic of Urology, İstanbul, Turkey
}

\section{What's known on the subject? and What does the study add?}

This study was designed for to critical review of the management complicated patients whom ureter stone is impacted. Because we think impacted ureter stone managament, especially on complicated cases, must be different from patients whom stone is ordinay.

\begin{abstract}
Objective

To evaluate ureteroscopy (URS) outcomes and management of perforations in impacted ureteral stones.

\section{Materials and Methods}

We retrospectively evaluated data from 81 patients who had undergone URS for impacted ureteral stones. Per-operative complications were evaluated visually and retrograde ureterography was performed when needed. Injuries of less than $50 \%$ around the ureter were classified as minor perforation and greater levels, as major perforation. Perforations were treated by double-j stent or a primary repair with consideration of the perforation grade.
\end{abstract}

Results

The stone-free rate was $69 \%$ on the first URS attempt and $79 \%$ at the end of 3 months. Complications occurred in $34(42 \%)$ patients. Minor perforation occurred in five patients and only double-j insertion was performed at the end of the procedure. Permanent ureteral stricture occurred in four of five patients. Three patients were treated by open ureterolithotomy, fibrotic segment resection and ureteroureterostomy due to major perforations. Transient or permanent ureteral stricture occurred in none of the three patients. The stricture rate was significantly higher in patients who were treated with double-j stent ( $80 \%$ vs. $0 \% p=0.028$ ) although they had lower perforation rate. Upper location, bigger size $(>10 \mathrm{~mm})$ of the ureteral stones and not using smash and go strategy were found to be significant predictors of complications.

\section{Conclusion}

URS for impacted ureteral stone has low success and high complication rates, especially for proximal and big stones. The conservative treatment may fail and result in stricture when perforation is present. Therefore, perforation treatment must be done by fibrotic segment excision and ureteroureterostomy.

\section{Keywords}

Impacted ureter stone, ureteroscopy, ureter stricture

\section{ÖZ}

Amaç

İmpakte üreter taşı olan hastalara yapılan üreteroskopinin sonuçlarını ve gelişen perforasyonların yönetimini değerlendirmeyi amaçladık.

Gereç ve Yöntem

İmpakte üreter taşı için opere edilen 81 hastanın verileri retrospektif olarak incelendi. Operasyon sırasında gelişen komplikasyonlar görsel olarak değerlendirildi, gereğinde retrograd üreterografi çekildi. Perforasyonun üreter çevresinin \%50'sinden küçük olduğu yaralanmalara minör, büyük olmasına da majör perforasyon denildi. Perforasyonun evresine göre sadece double-j stent ile veya açık onarımla tedavi yapıldı.

\section{Bulgular}

İlk seansta tam taşsızıı oranı \%69 olarak bulunurken, 3. ayın sonunda bu oran \%79 idi. Komplikasyon 34 (\%42) hastada gelişti. Minör perforasyon beş hastada gelişti. Bunların tamamına işlem sonunda double-j stent kondu. Bu beş hastanın dördünde (\%80) kalıcı darlık gelişti. Major perforasyon gelişen üç hasta ise açık operasyona geçilerek fibrotik segment rezeke edilip taş alındıktan sonra uç uca anastomoz yapılarak tedavi edildi. Bu üç hastanın hiçbirinde darlık gelişmedi. Striktür oranı sadece double-j ile tedavi edilenlerde perforasyon oranı daha düşük olmasına karşın anlamlı olarak daha yüksekti ( $\% 80$ 'e karşı $\% 0$ p=0,028). Taşın üst lokalizasyonda ve $10 \mathrm{~mm}$ 'den büyük olması, kır-bırak stratejisinin kullanılmaması da komplikasyonları predikte eden faktörler olarak tespit edildi.

\section{Sonuç}

İmpakte üreter taşlarında, özellikle üst lokalizasyonda ve 10 mm'den büyük olanlarda, üreteroskopi düşük başarı ve yüksek komplikasyon oranına sahiptir. Perforasyon geliştiğinde ise konservatif tedavinin başarı şansı çok düşüktür. Bu nedenle perforasyon geliştiğinde açık operasyona geçilerek fibrotik segment rezeke edilmeli ve uç uca anastomoz yapılmalıdır.

\section{Anahtar Kelimeler}

İmpakte üreter taşı, üreteroskopi, üreter striktürü

\section{Correspondence}

Göksel Bayar MD, İdil State Hospital, Clinic of Urology, Şırnak, Turkey

Phone: +90 2323244543 E-mail: goxelle@yahoo.com Received: 21.04.2016 Accepted: 21.08.2016 


\section{Introduction}

Treatment of ureter stones are determined by stone size, localization, impaction, severity of symptoms, degree of obstruction, renal function and accompanying urinary tract infection (1). The term "impacted stone" is identified by calculi that remain in the same position for at least one month and cause ureteral obstruction with no visualization of contrast medium beyond the stone on intravenous urography (IVU) or sensor guide cannot pass around the stone (2).

Shock wave lithotripsy (SWL) and ureteroscopy (URS) are most common treatment methods for ureteral stones with low complication and high success rates $(3,4,5)$. However, success rate of SWL is not high in impacted ureteral stones, because there is not enough area around the stone for expansion by virtue of inflammation and edema $(6,7,8)$. Therefore, the first choice must be URS in impacted ureter stones (9). The URS success rate is higher than SWL, but its complication rate is high. Ureteral perforation and ureteral stricture are worrying complications due to unclear management (10).

We aimed to share our experience with URS outcomes and management of complications associated with impacted ureteral stones.

\section{Material and Methods}

We retrospectively evaluated data from patients who had undergone URS for impacted ureteral stones between 2008 and 2014. Patients whose data was insufficient and whose follow-up time was less than 3 months were excluded. The size of the opaque stones was measured by direct radiography and non-opaque ones, by computed tomography. The long axis was accepted definitive stone size. Stone surface area was calculated by the formula: length $\mathrm{x}$ width $\mathrm{x} \pi \mathrm{x}$ 0.25 . Preoperatively, routine blood and urine tests were done in all patients. Urine culture was performed in patients whose urine tests were abnormal. Antibiotics were given to the patients according to the results of the antibiotic susceptibility testing. Operation was done afterwards when urine culture was negative. Routine antibiotic prophylaxis was performed in all patients in whom culture was negative. All operations were performed under general anesthesia. Firstly, $8 \mathrm{Fr}$ ureteroscope was used for accessing to ureter stones. It was exchanged to $6 \mathrm{Fr}$ ureteroscope if access could not be achieved. Balloon dilatation was used when the access was not gained by 6 Fr ureteroscope. A guidewire with sensor tip was used for access to the ureter through ureteroscope. A flexible 7.5 Fr ureteroscope was used when access has not been gained by semirigid ureteroscopes for middle and proximal ureter. Laser or pneumatic power sources were used for lithotripsy. Stone-free was accepted as all stones were cleaned using basket or $n$-trap or broken to a maximum size of $3 \mathrm{~mm}$ by a smash and go method. A double-j stent was inserted in all patients at the end of the operation. All of the operation was performed by only one urologist or senior trainee under the supervision of the same urologist.

The Clavien-Dindo classification was used to classify complications. Per-operative complications were evaluated visually and retrograde ureterography was done when needed. Perforations were treated by double-j stent insertion or a primary repair with consideration of the perforation grade. Classification of the ureter injury was done by referencing the Organ Injury Scaling prepared by the American Association for the Surgery of Trauma (11). According to this classification, injury involving less than 50\% of circumference of the ureter is grade 2, and a greater level is classified as grade 3 . We classified minimal extravasation as grade 2, manifest extravasation and non-visible kidney as grade 3 on retrograde ureterography. Grade 2 perforation was classified as minor and grade 3 perforation, as major. A double-j stent was inserted for minor perforations, and open repair was performed in patients with major perforations.

IVU was performed in patients who had hydronephrosis 3 months later. If hydronephrosis persisted, IVU would be repeated 6 months later. It was accepted as ureteral stricture when stenosis was observed in the same location on both IVU. Balloon dilatation and double-j stent insertion were performed at least twice. If a stricture was not corrected at the end of both procedures, it was accepted as permanent. Stricture excision and ureteroureterostomy were performed in patients who had permanent stricture.

\section{Statistical Analysis}

Patient demographics, stone location, size and surface area, power source for lithotripsy, lithotripsy strategy, operation success, complications, and management of complications were evaluated. SPSS 15 for Windows (Chicago, II) was used for statistical analysis. The Mann-Whitney $\mathrm{U}$ and Pearson's chi-squared tests were performed. A $p$ value of less than 0.05 was considered statistically significant.

\section{Results}

A total of 81 patients were included in the study. Patient demographics and operative findings are shown on Table 1. The stone-free rate was $69 \%$ on the first session of URS. The stone-free rate was 79\% at the end of 3 months with SWL (five patients), re-URS (two patients) and percutaneous nephrolithotomy (PNL) (one patient). Open or laparoscopic ureterolithotomy was performed in the remaining 17 patients whenever stones could not be accessed. The median follow-

\begin{tabular}{|l|l|}
\hline \multicolumn{2}{|l|}{ Table 1. Patients' demographic and descriptive data } \\
\hline $\begin{array}{l}\text { Mean age } \pm \text { SD (years) (minimum- } \\
\text { maximum) }\end{array}$ & $39 \pm 16$ (6-76) \\
\hline Gender (male/female) & $41 / 40$ \\
\hline Laterality (right/left) & $39 / 42$ \\
\hline Location & Proximal: $31(38 \%)$ \\
\hline & Middle: $16(20 \%)$ \\
\hline & Distal: 34 (42\%) \\
\hline Mean stone size \pm SD and surface \pm SD & $11.5 \pm 5.2$ mm and 102 $\pm 94 \mathrm{~mm}^{2}$ \\
\hline Power source & Laser: 22 (27\%) \\
\hline & Pneumatic: 42 (52\%) \\
\hline & None: 17 (21\%) \\
\hline "Smash and Go" strategy performed & 34 (42\%) \\
\hline Success rate with URS and SWL & $\begin{array}{l}\text { th day: } 69 \% \\
3 \text { rd month: } 79 \%\end{array}$ \\
\hline Complication number (n) & 34 (42\%) \\
\hline $\begin{array}{l}\text { Median follow-up (months) (minimum- } \\
\text { maximum) }\end{array}$ & 7 (3-86) \\
\hline SD: Standard deviation, URS: Ureteroscopy, SWL: Shock wave lithotripsy \\
\hline
\end{tabular}


up time was 7 (3-86) months for all patients and 12 (3-86) months for complicated patients.

Complications occurred in $34(42 \%)$ patients. Grade 1 or 2 complications occurred in 12, grade $3 a$ in 11 , grade $3 b$ in ten patients, and grade 4 in one patient (Table 2). The details for grade 3a complicated patients are as follows: hematoma in the bladder was evacuated in one patient, SWL was performed on five patients due to stone migration, and minor perforation occurred in five patients and only double-j insertion was performed at the end of the procedure. Permanent ureteral stricture occurred in four of five patients. Three of four patients were treated by excision of the fibrotic segment and open ureteroureterostomy. Due to patient's age and co-morbidity, regular double-j stent changing was performed with 6 month intervals in the other patient.

Grade 3b complicated patients' details are as follows: URS was performed in one patient for steinstrasse. Percutaneous drainage and double-j insertion were performed in one patient due to urinoma. Stone migration was treated by flexible URS in two patients and by PNL in one patient. Three patients were treated by open ureterolithotomy, fibrotic segment resection and ureteroureterostomy due to major perforations. Transient or permanent ureteral stricture occurred in none of the three patients.

Permanent stricture occurred in four of five patients who were treated only by double-j stenting, and in none of the three patients who were treated with an open procedure. This was statistically significant (80\% vs. $0 \% p=0.028$ ). Ureteral stricture was determined in four patients but no perforation occurred. Stone size was greater than $10 \mathrm{~mm}$ in these patients. These patients were treated by balloon dilatation and double-j insertion, and permanent stricture did not occur in any of them.

Table 2. All of complications of ureteroscopy classified according to modified Clavien classification system

\begin{tabular}{|c|c|c|}
\hline Grade & Complication & $N(\%)$ \\
\hline \multirow{2}{*}{ I } & Mucosal injury & $5(6.1)$ \\
\hline & Hematuria & $2(2.5)$ \\
\hline \multirow{2}{*}{ II } & Blood transfusion & $1(1.5)$ \\
\hline & Urinary tract infection & $4(4.9)$ \\
\hline \multirow{3}{*}{ IIla } & Bladder hematoma & $1(1.5)$ \\
\hline & Minor perforation & $5(6.1)$ \\
\hline & Stone migration* & $5(6.1)$ \\
\hline \multirow{4}{*}{ IIlb } & Urinoma & $1(1.5)$ \\
\hline & Steinstrasse & $1(1.5)$ \\
\hline & Stone migration* & $3(3.7)$ \\
\hline & Major perforation & $3(3.7)$ \\
\hline$\| l \mid b . d^{* *}$ & Ureteral avulsion & $2(2.5)$ \\
\hline IVa & Organ failure & 0 \\
\hline $\mathrm{IVb}$ & Urosepsis & $1(1.5)$ \\
\hline V & Death & 0 \\
\hline \multicolumn{2}{|l|}{ Total } & $34(42)$ \\
\hline \multicolumn{3}{|c|}{$\begin{array}{l}\text { *Stone migration was classified as IIla when treated with SW or IIIb with re- } \\
\text { ureteroscopy, percutaneous nephrolithotomy or open procedure, }{ }^{* *} \text { Two patients were } \\
\text { classified as Illb.d because of nephrectomy, URS: Ureteroscopy, PNL: Percutaneous } \\
\text { nephrolithotomy }\end{array}$} \\
\hline
\end{tabular}

Ureteral avulsion occurred in two patients. The stones were at proximal locations and were larger than $10 \mathrm{~mm}$ in these patients. End-to-end anastomosis and omental wrapping was performed in one patient as an emergency procedure. We performed nephrectomy two days later due to ureter necrosis seen on contrast-enhanced computed tomography. Ureteral substitution was performed using ileum in the other patient, but nephrectomy was performed due to abscess and non-response to medical treatment. Therefore, these patients were classified as Clavien IIlb.d.

In the univariate analysis, upper location $(p=0.001)$ and large size $(>10$ $\mathrm{mm})(p=0.014)$ of the ureteral stones were found to be a significant predictor of complications. Furthermore, we have seen that a smash and go strategy was preferred for non-complicated patients ( $p=0.026$ ). Age, gender, lateralization, operator, balloon dilatation performance, and power source were not significance factors for the prediction of complications (Table 3).

\section{Discussion}

The choice of therapy for a ureteral stone depends on the stone size and location. However, appropriate treatment for impacted stones is not yet clear. SWL treatment success is $67 \%$ at the end of the first month (12). The semi-rigid URS success rate is about $80 \%$ with the additive procedures of SWL and re-URS at end of 3 months $(12,13)$. Our success rate was 69\% in the first procedure and 79\% with SWL and re-URS. The results show that impacted ureteral stones might necessitate additive procedures.

The complication rate is high in URS for impacted stones. Stone size and location are the most predictive factors for complication. Brito et al. (14) reported that complication was not seen in situation with a stone size smaller than $5 \mathrm{~mm}$, but complication was seen with stones larger than $5 \mathrm{~mm}$, and complication rate was the highest in situations with stones larger than $10 \mathrm{~mm}$. We have seen that the complication rate is 2 fold higher in stones larger than $10 \mathrm{~mm}$ than in smaller stones ( $53 \%$ vs. $26 \% p=0.01$ ). Another study also showed that proximal location increases the complication risk by about 2 fold (13).

Table 3. Association between of pre or intraoperative parameters and complication rates

\begin{tabular}{|l|l|l|l|}
\hline & $\begin{array}{l}\text { Complicate } \\
(\mathrm{n}=34)(\% 42)\end{array}$ & $\begin{array}{l}\text { Non complicate } \\
(\mathrm{n}=47)(\% 58)\end{array}$ & $p$ value \\
\hline Gender (male) & $18(53)$ & $23(49)$ & .31 \\
\hline Age & $40.5 \pm 18$ & $38 \pm 14$ & .40 \\
\hline Laterality (right) & $18(53)$ & $21(45)$ & .72 \\
\hline Location (proximal) & $22(64)$ & $9(19)$ & $.001^{*}$ \\
\hline Stone size (>10 mm) & $25(73)$ & $22(47)$ & $.014^{*}$ \\
\hline $\begin{array}{l}\text { Mean stone size } \pm \text { SD } \\
\text { (mm) and surface } \pm \text { SD } \\
\text { (mm²) }\end{array}$ & $14 \pm 5.5(110 \pm 65)$ & $8.5 \pm 4.5(50 \pm 26)$ & $.001^{*}$ \\
\hline Operator (urologist) & $24(71)$ & $30(64)$ & .12 \\
\hline Balloon dilatation & $3(9)$ & $3(6)$ & .23 \\
\hline "BSmash and Go" & $9(27)$ & $25(53)$ & $.026^{*}$ \\
\hline Power source (laser) & $8(24)$ & $14(29)$ & 0.35 \\
\hline *p value is significant at <0.05 level, SD: Standard deviation \\
\hline
\end{tabular}


Flexible URS can be used for proximal ureter stones to decrease complication rate and increase success rate. Success rate increase by flexible URS, but complication rate does not (13). It has been seen in our study and elsewhere that the choice of power source for lithotripsy, laser or pneumatic, does not change the complication rate $(13,15)$.

Stricture rate is $0.1-0.3 \%$ in URS series $(16,17)$. However, the rate is high in impacted stones. Stricture may occur if a patient was treated for impacted ureter stone despite no perforation being present. Ureteral stricture pathophysiology is not clear yet. Ureteral injury, large caliber URS use and thermal damage may be reasons for stricture (10). Chronic inflammation, interstitial fibrosis and urothelial hypertrophy were determined to be around impacted stones in histological studies $(4,6)$. Calcium oxalate crystals were determined to be in the stricture area in patients who had remaining stones. This finding has shown that remaining stones can trigger stricture formation $(6,18)$. Therefore, smash and go strategy can decrease complication rates, but can also cause ureteral stricture due to remaining stones in patients with impacted ureteral stones. Furthermore, urine extravasation can cause retroperitoneal fibrosis and ureteral stricture (19). Ureteral stricture can occur with impacted stones regardless of complication development (10). However, perforation increased the stricture rate about 14 fold in our study (5.6\% vs. 80\%). Brito et al. (14) reported that perforation rate was 55\% in impacted ureteral stones and stricture would be at a rate of $75 \%$ if perforation occurred. Permanent stricture occurred in four of five patients in whom the ureter was perforated and treated only by double-j stent, but stricture occurred in none of the three patients treated with open procedures in our study. Ureteral stricture occurred in 4 of 71 (5.6\%) patients in whom the ureter was not perforated. Four patients were treated only with balloon dilatation and double-j stent. This shows that management of perforation must be different for impacted stones. Open ureteroureterostomy can prevent stricture regardless of the perforation size, and balloon dilatation cannot treat strictures in patients in whom ureter perforation is present. However, balloon dilatation is sufficient in treating ureteral stricture not due to perforation.

Alternative methods for the treatment of impacted ureter stones have been sought due to high complication and low success rates. Antegrade percutaneous URS was done for proximal ureter stones. The success rate was high (85-100\%), but complication (20\%) and perforation (9\%) rates were also high $(20,21)$. Ureterolithotomy, open or laparoscopic, has a high success rate (90-100\%) and low complication (2-10\%) and stricture rates $(0-1 \%)(22,23,24)$. The European Association of Urology guidelines recommend alternative methods, such as antegrade URS or ureterolithotomy, for impacted ureter stones as a first choice based on the physician's experience; but open and laparoscopic ureterolithotomy are expensive treatment methods (1).

Avulsion is the most terrible complication. Treatment options are as follows: Boari flap, psoas hitch, transureteroureterostomy, autotransplantation, ileal interposition and appendix interposition. We have done end-to-end anastomosis in one case, and ileal interposition in one case. Both of them failed and we had to do nephrectomy. Endto-end anastomosis has been successful in one of three cases in the literature and it is not recommended $(25,26)$. Auto-transplantation is the most promising method for proximal avulsion. Ileal or appendix interposition will do if auto-transplantation is not possible (27).
The retrospective nature and low number of patients may be a limitation of our study. It is overcome by multi institutional working.

\section{Conclusions}

URS for impacted ureteral stone has low success and high complication rates. It is not an appropriate method especially for proximal and large stones. Patients must be informed about complications. Open or laparoscopic ureterolithotomy may be recommended for patients who have large stones or stones at proximal locations. The conservative treatment, a double-j stent insertion, may fail and finalize as stricture when perforation is present. Therefore, perforation treatment must be done by fibrotic segment excision and ureteroureterostomy.

\section{Ethics}

Ethics Committee Approval: Ethics committee approval was not obtained because this was a retrospective study. Informed consent: Written informed consent was not obtained from patients because this was a retrospective study.

Peer-review: Internal peer-reviewed.

\section{Authorship Contributions}

Concept: Göksel Bayar, Orhan Tanrıverdi, Design: Göksel Bayar, Orhan Tanrıverdi, Data Collection or Processing: Kaya Horasanlı, Ayhan Dalkılıç, Analysis or Interpretation: Orhan Tanrıverdi, Kaya Horasanlı, Literature Research: Göksel Bayar, Kaya Horasanlı, Writing: Göksel Bayar, Ayhan Dalkılıç.

Conflict of Interest: No conflict of interest was declared by the authors.

Financial Disclosure: The authors declared that this study has received no financial support.

\section{References}

1. Turk C, Knoll T, Petrik A, Sarica K, Skolarikos A, Straub M, Seitz C. European Urology. Guidelines on Urolithiasis 2015. Available at http://uroweb.org/ wp-content/uploads/EAU-Guidelines-Urolithiasis-2015-v2.pdf

2. Elganainy $E$, Hameed DA, Elgammal MA, Abd-Elsayed AA, Shalaby M. Experience with impacted upper ureteral stones; should we abandon using semirigid ureteroscopes and pneumatic lithoclast? Int Arch Med 2009;3;2:13.

3. Goel R, Aron M, Kesarwani PK, Dogra PN, Hemal AK, Gupta NP. Percutaneous antegrade removal of impacted upper-ureteral calculi: still the treatment of choise in developing countries. J Endourol 2005;19:54-57.

4. Morgentaler A, Bridge SS, Dretler SP. Management of the impacted ureteral calculus J Urol 1990;143:263-266.

5. Erhard M, Salwen J, Bagley DH. Ureteroscopic removal of mid and proximal ureteral calculi. J Urol 1996;155:38-42.

6. Dretler SP, Keating MA, Riley J. An algorithm for the management of ureteral calculi. J Urol 1986;136:1190-1193.

7. Chaussy CG, Fuchs GJ. Current state and future developments of noninvasive treatment of human urinary stones with extracorporeal shock wave lithotripsy. J Urol 1989;141:782-789.

8. Chambo JL, Mitre Al, El Hayek OR, Brito AH, Arap S. Experiencia com um novo tipo de litotridor intracorporeo: litotridor balistico-pneumatico Swiss Litoclast. J Bras Urol 1996;22:68-70.

9. Mugiya S, Nagata M, Un-No T, Takayama T, Suzuki K, Fujita K. Endoscopic management of impacted ureteral stones using a small caliber ureteroscope and a laser lithotriptor. J Urol 2000;164:329-331.

10. Roberts WW, Cadeddu JA, Micali S, Kavoussi LR, Moore RG. Ureteral stricture formation after removal of impacted calculi. J Urol 1998;159:723-726. 
11. Moore EE, Cogbill TH, Jurkovich GJ, McAninch JW, Champion HR, Gennarelli TA, Malangoni MA, Shackford SR, Trafton PG. Organ injury scaling. III: Chest wall, abdominal vascular, ureter, bladder, and urethra. J Trauma 1992; 33:337-339.

12. Khalil M. Management of impacted proximal ureteral stone: Extracorporeal shock wave lithotripsy versus ureteroscopy with holmium: YAG laser lithotripsy. Urol Ann 2013;5:88-92.

13. Degirmenci T, Gunlusoy B, Kozacioglu Z, Arslan M, Koras O, Arslan B, Minareci S. Comparison of $\mathrm{Ho}: Y A G$ laser and pneumatic lithotripsy in the treatment of impacted ureteral stones: an analysis of risk factors. Kaohsiung J Med Sci 2014;30:153-158.

14. Brito AH, Mitre Al, Srougi M. Ureteroscopic pneumatic lithotripsy of impacted ureteral calculi. Int Braz J Urol 2006;32:295-299.

15. Binbay $M$, Tepeler $A$, Singh $A$, Akman T, Tekinaslan $E$, Sarilar 0 , Baykal M, Muslumanoglu AY. Evaluation of pneumatic versus holmium: YAG laser lithotripsy for impacted ureteral stones. Int Urol Nephrol 2011;43:989995.

16. Geavlete P, Georgescu D, Nita G, Mirciulescu V, Cauni V. Complications of 2735 retrograde semirigid ureteroscopy procedures: a single-center experience. J Endourol 2006;20:179-185.

17. De la Rosette J, Denstedt J, Geavlete P, Keeley F, Matsuda T, Pearle M, Preminger G, Traxer 0; CROES URS Study Group. The clinical research office of the endourological society ureteroscopy global study: indications, complications, and outcomes in 11.885 patients. J Endourol 2014;28:131-139.

18. Mueller SC, Wilbert D, Thueroff JW, Alken P. Extracorporeal shock wave lithotripsy of ureteral stones: clinical experience and experimental findings. J Urol 1986;135:831-834.
19. Mitchinson MJ, Bird DR. Urinary leakage and retroperitoneal fibrosis. J Urol 1971;105:56-58.

20. Kumar V, Ahlawat $R$, Banjeree GK, Bhaduria RP, Elhence A, Bhandari M. Percutaneous ureterolitholapaxy: the best bet to clear large bulk impacted upper ureteral calculi. Arch Esp Urol 1996;49:86-91.

21. Moufid K, Abbaka N, Touiti D, Adermouch L, Amine M, Lezrek M. Large impacted upper ureteral calculi: A comparative study between retrograde ureterolithotripsy and percutaneous antegrade ureterolithotripsy in the modified lateral position. Urol Ann 2013;5:140-146.

22. Bayar G, Tanriverdi O, Taskiran M, Sariogullari U, Acinikli H, Abdullayev E, Horasanli K, Miroglu C. Comparison of laparoscopic and open ureterolithotomy in impacted and very large ureteral stones. Urol J 2014;11:1423-1428.

23. Ma L, Yu DM, Zhang ZG, Li GH, Ding GQ, Chen YB, Xu LW, Wu HY, Cai XJ. Transperitoneal laparoscopic ureterolithotomy for upper ureteral calculi: a report of 1171 cases. Zhonghua Yi Xue Za Zhi 2013;93:1577-1579.

24. Meitei SK, Lodh B, Khumukcham S, Gupta S, Singh KA, Sinam RS. Evaluation of safety and efficacy of open mini-access ureterolithotomy in the era of minimally invasive surgery. Urol J 2014;11:1583-1588.

25. Ge C, Li O, Wang L, Jin F, Li Y, Wan J, Lan W, Liang P. Management of complete ureteral avulsion and literature review: a report on four cases. J Endourol 2011;25:323-326.

26. Unsal A, Oguz U, Tuncel A, Bozkurt OF, Aslan Y, Eraslan A, Senocak Ç, Atan $A$. How to manage total avulsion of the ureter from both ends: our experience and literature review. Int Urol Nephrol 2013;45:1553-1560.

27. Alapont JM, Broseta $E$, Oliver $F$, Pontones $J L$, Boronat $F$, Jiménez-Cruz JF. Ureteral avulsion as a complication of ureteroscopy. Int Braz J Urol 2003;29:18-22. 